\title{
Influence of Processing Parameters on Structural Characteristics of Porous Calcium Phosphate Samples: A Study Using an Experimental Design Method
}

\author{
José Fernandes de Oliveira Ugartea, Lidia Ágata de Sena a , Carlos André de Castro Pérez, \\ Paula Fernandes de Aguiarc, Alexandre Malta Rossi ${ }^{\mathrm{d}}$, Glória Almeida Soares ${ }^{\mathrm{a} *}$ \\ a Materials Engineering Department, Federal University of Rio de Janeiro, \\ P.O.Box 68505, 21941-972 Rio de Janeiro - RJ, Brazil \\ ${ }^{\mathrm{b}}$ Chemical Engineering Department, Federal University of Rio de Janeiro, \\ P.O.Box 68502, 21941-972 Rio de Janeiro - RJ, Brazil \\ ${ }^{\mathrm{D}}$ Department of Analytical Chemistry, Chemistry Institute, Federal University of Rio de Janeiro, \\ 21949-900 Rio de Janeiro - RJ, Brazil \\ ${ }^{\mathrm{d}}$ Brazilian Center for Physics Research $(C B P F)$, \\ Rua Xavier Sigaud 150, 22290-150 Rio de Janeiro - RJ, Brazil
}

Received: October 15, 2004; Revised: January 17, 2005

\begin{abstract}
Synthetic porous ceramics can be used as three-dimensional scaffolds for bone repair. The aim of this work is to correlate process parameters with scaffolds structural characteristics. The factorial 2 level experimental design was chosen to study the effect of the $\mathrm{Ca} / \mathrm{P}$ ratio $(1.58$ or 1.67$)$, calcination temperature $\left(1000\right.$ or $\left.1150{ }^{\circ} \mathrm{C}\right)$ and porogen content (20 or $40 \%$ ) on the calcium phosphate samples characteristics. The influence of such parameters was determined by X-ray diffraction, infrared spectroscopy and image analysis. It was observed that phase composition was basically a function of the $\mathrm{Ca} / \mathrm{P}$ ratio of the raw material. The use of the porogen did not alter the hydroxyapatite (HA)/tricalcium phosphate (TCP) content, but induced changes in the relative content of TCP phase ( $\alpha$ or $\beta$ ). It is possible to design a porous sample with defined characteristics, and the model herein used can be considered as having a good predictive power.
\end{abstract}

Keywords: scaffolds, calcium phosphate, biomedical applications

\section{Introduction}

Bone tissue engineering is highly dependent on the development of materials science and technology ${ }^{1}$. A variety of calcium phosphates have been used for bone engineering applications ${ }^{1-5}$. Hydroxyapatite (HA) and other calcium phosphates, like tricalcium phosphate (TCP), are considered osteoconductive materials allowing the formation of a new bone around the implant or inside their pores ${ }^{6,7}$. On the other hand, osteoinductive mater ials induce the differentiation of pluripotential cells into chondrocytes and osteoblasts ${ }^{1}$. Composite materials with collagen ${ }^{1,8,9}$ have been developed with the purpose of stimulating bone formation.

Calcium phosphate based materials have been studied since the $80^{\prime}$ s, and during the past two decades research has aimed to correlate material properties with either in vitro ${ }^{4}$ or in vivo behavior ${ }^{10-14}$. Different applications require materials with different degradation rates, which can be regulated through the mixture of several calcium phosphate phases. The extent of calcium phosphate ceramics (CPC) dissolution in acidic buffer increases from synthetic hydroxyapatite to amorphous apatite, with tricalcium phosphate exhibiting medium solubility ${ }^{5}$. Recently, a paper has discussed the eight existing dissolution models for calcium apatites ${ }^{15}$. According to the authors, none of the dissolution models is capable of accurately describing the dissolution process. Rather, those models are assumed to complement each other providing the correct description of some aspects of apatite dissolution. In another paper, Dorozhkina and Dorozhkin ${ }^{16}$ described the mechanisms of the solid state transformation of a calcium-deficient calcium phosphate (CD-HA) into biphasic calcium phosphate (BCP) at elevated temperatures as being an alternative route to obtain $\mathrm{BCP}$ materials from the physical mixture.
A problem related to synthetic calcium phosphate materials is their low mechanical strength. Furthermore, this mechanical strength is largely reduced by high fraction of interconnected macropores, which are desired for either in vivo bone formation or for application as a carrier for bone cells. Several researchers have pointed out the necessity of pores with at least 100-150 $\mu \mathrm{m}$ diameters for the continued bone ingrowth ${ }^{14}$, while Baksh and Davies ${ }^{17}$ have suggested even larger pores for cells incorporation to the synthetic material. According to Holmes ${ }^{\text {apud }} 1$, the optimal pore range is $200-400 \mu \mathrm{m}$ with the average human osteon size of approximately $220 \mu \mathrm{m}$. Burg et $\mathrm{al}^{1}$ also discuss the effect of pore shape and topography on the attachment and long-term survival of cells on a surface.

Therefore, the challenge is to develop synthetic materials with high porosity, a known and controlled degradation rate and suitable mechanical properties ${ }^{18-19}$. Those materials (in blocks or samples form) may be fabricated by uniaxial or isostatic pressing, adding an organic porogen that will burn out during sintering, originating the necessary macroporosity. Several process parameters such as chemical composition and granulometry of raw material; compressive stress and time under pressure; and calcination temperature may affect material integrity ${ }^{19,20}$. The final porosity depends on such parameters and on chemical composition, particle size and quantity of the porogen used $^{21}$. In addition, The $\mathrm{Ca} / \mathrm{P}$ ratio determines the decomposition behavior of the calcium phosphate when it is submitted to treatment at high temperatures, as well as its dissolution properties s,5,16. $^{4}$.

Experimental designs may be a useful tool to deal with optimization of several parameters at the same time. This multivariate approach has been applied in many fields and, in this work, it has 
shown to be a reasonable means to determine the optimal conditions to synthesize materials with the desired characteristics ${ }^{22}$. The factorial 2 experimental design was chosen to study the effect of the variation of three parameters on the product characteristics $\left(2^{3}\right.$ design $)$.

In this paper, samples were produced in eight different conditions and were characterized by different techniques. The process parameters chosen were $\mathrm{Ca} / \mathrm{P}$ ratio, calcination temperature and porogen percentage. The influence of those parameters on phase transformation and pore distribution of the calcium phosphate samples was discussed. A mathematical relationship was determined and its validity was evaluated.

\section{Materials and Methods}

Stoichiometric $(\mathrm{S}-\mathrm{HA}, \mathrm{Ca} / \mathrm{P}=1.67)$ and calcium-deficient $(\mathrm{CD}$ $\mathrm{HA}, \mathrm{Ca} / \mathrm{P}=1.58$ ) hydroxyapatite powders were synthesized from dropwise addition of an $\left(\mathrm{NH}_{4}\right)_{2} \mathrm{HPO}_{4}$ aqueous solution to a $\mathrm{Ca}\left(\mathrm{NO}_{3}\right)_{2}$ solution at $90{ }^{\circ} \mathrm{C}$ and $\mathrm{pH}=11$, using analytical grade reagents. The precipitate was separated by filtration, repeatedly washed with deionized water and dried at $100{ }^{\circ} \mathrm{C}$ for 24 hours. The dried powder was manually ground and the fraction of particles below $75 \mu \mathrm{m}$ was separated by sieving. Naphthalene powder with grain size $>250 \mu \mathrm{m}$ was used as additive to calcium phosphate in order to promote sample porosity. Cylindrical samples with $12 \mathrm{~mm}$ of diameter and $8 \mathrm{~mm}$ height were prepared from the S-HA-naphthalene and CD-HA-naphthalene mixtures by uniaxial cold pressing at $37 \mathrm{MPa}$.

Table 1 shows the eight calcium phosphate conditions that were yielded by varying the following parameters: the calcium phosphate $\mathrm{Ca} / \mathrm{P}$ ratio, the percentage of organic additive used to promote macroporosity in the samples and the calcination temperature. Two levels of each parameter were evaluated: $\mathrm{Ca} / \mathrm{P}$ ratio of 1.58 and 1.67 , corresponding to calcium-deficient $(\mathrm{CD})$ and stoichiometric $(\mathrm{S})$ hydroxyapatite (HA), respectively; 20 or $40 \mathrm{wt}$. (\%) of naphthalene and two calcination temperatures, namely 1000 or $1150{ }^{\circ} \mathrm{C}$, with a dwell time of 2 hours.

Pore morphology was characterized by microscopy using a scanning electron microscope (SEM, DSM 940A, Carl Zeiss, Germany). The total porosity was determined by the density method using the expression: $\mathrm{TP}=1-\left(\rho_{\text {real }} / \rho_{\text {theor }}\right)$, where $\rho_{\text {theor }}$ is the theoretical density of HA (or HA-TCP mixture) in $\mathrm{kg} / \mathrm{m}^{3}$ and $\rho_{\text {real }}$ is calculated dividing the weight (in $\mathrm{kg}$ ) by the volume (in $\mathrm{m}^{3}$ ) of each sample ${ }^{21}$. This porosity included both open and closed pores and was measured in eight samples for each condition. The percentage of pores with diameters in the range $<100,100-200,200-300,300-400$ and $>400 \mu \mathrm{m}$ was also determined by processing SEM digital images of samples

Table 1. Porous samples produced following a $2^{3}$ factorial design. Two levels of each parameter were evaluated: $\mathrm{Ca} / \mathrm{P}$ ratio of 1.67 (S-HA) and 1.58 (CDHA); 20 or $40 \mathrm{wt}$. (\%) of naphthalene and two calcination temperatures $\left(1000\right.$ or $\left.1150{ }^{\circ} \mathrm{C}\right)$.

\begin{tabular}{|c|c|c|c|c|c|c|}
\hline \multirow[t]{2}{*}{ Sample } & \multicolumn{2}{|c|}{$\begin{array}{l}\mathrm{Ca} / \mathrm{P} \\
\text { Ratio }\end{array}$} & \multicolumn{2}{|c|}{$\begin{array}{l}\text { Naphthalene } \\
\text { (wt. }(\%))\end{array}$} & \multicolumn{2}{|c|}{$\begin{array}{l}\text { Calcination } \\
\text { Temp. }\left({ }^{\circ} \mathrm{C}\right)\end{array}$} \\
\hline & S-HA & CD-HA & 20 & 40 & 1000 & 1150 \\
\hline S-20-1000 & $\mathrm{x}$ & & $\mathrm{X}$ & & $\mathrm{x}$ & \\
\hline S-20-1150 & $\mathrm{x}$ & & $\mathrm{x}$ & & & $\mathrm{x}$ \\
\hline S-40-1000 & $\mathrm{x}$ & & & $\mathrm{x}$ & $\mathrm{x}$ & \\
\hline S-40-1150 & $\mathrm{x}$ & & & $\mathrm{x}$ & & $\mathrm{x}$ \\
\hline CD-20-1000 & & $\mathrm{x}$ & $\mathrm{x}$ & & $\mathrm{x}$ & \\
\hline CD-20-1150 & & $\mathrm{x}$ & $\mathrm{x}$ & & & $\mathrm{x}$ \\
\hline CD-40-1000 & & $\mathrm{x}$ & & $\mathrm{x}$ & $\mathrm{x}$ & \\
\hline CD-40-1150 & & $\mathrm{x}$ & & $\mathrm{X}$ & & $\mathrm{x}$ \\
\hline
\end{tabular}

calcined at $1000{ }^{\circ} \mathrm{C}$. Nine images of each sample were acquired by using backscattered electrons and were processed by using the Global Lab Image software (Data Translation, Marlboro, MA, USA). The histograms of pore size distribution were then constructed.

Structural characterization was carried out by using an X-ray diffractrometer (XRD - MINIFLEX, Rigaku, Tokyo, Japan) operating at $30 \mathrm{kV}, 15 \mathrm{~mA}$ and $\mathrm{CuK} \alpha$ radiation. Data was acquired from $10-100^{\circ} 2 \theta$. The HA and TCP phase contents were determined by using the Rietveld method with the FULLPROF analysis program described by Rodriguez-Carvajal ${ }^{23}$. The background was defined by a three-parameter polynomial in $2 \theta^{n}$, where $n$ had values between 0 and 2 , and it was refined simultaneously with the unit-cell, zeropoint scale, peak-width/shape/asymmetry, and crystal-structure parameters. A Fourier-transform infrared spectrometer, FTIR, ABB Bomem Inc., MB series, equipped with reflectance stage was used in order to identify different phosphate species in the treated samples. The spectra were collected at room temperature at a nominal resolution of $4.00 \mathrm{~cm}^{-1}$ and number of sample scans equal to 1000 . The FTIR spectra were recorded in the $400-3800 \mathrm{~cm}^{-1}$ range using diffuse reflection.

The model proposed with the $2^{3}$ factorial design to describe the behavior of the HA phase content and total porosity in the studied intervals of variables is presented below:

$$
\begin{aligned}
& \mathrm{Y}=\mathrm{b}_{0}+\mathrm{b}_{1} \mathrm{x}_{1}+\mathrm{b}_{2} \mathrm{x}_{2}+\mathrm{b}_{3} \mathrm{x}_{3}+\mathrm{b}_{12} \mathrm{x}_{1} \mathrm{x}_{2}+\mathrm{b}_{13} \mathrm{x}_{1} \mathrm{x}_{3}+ \\
& \mathrm{b}_{23} \mathrm{x}_{2} \mathrm{x}_{3}+\mathrm{b}_{123} \mathrm{x}_{1} \mathrm{x}_{2} \mathrm{x}_{3}
\end{aligned}
$$

where $\mathrm{Y}$ represents the measured response (content of the phase HA, total porosity), and $\mathrm{x}_{1}, \mathrm{x}_{2}$ and $\mathrm{x}_{3}$ represent, respectively, calcium phosphate $\mathrm{Ca} / \mathrm{P}$ ratio, calcination temperature and naphthalene percentage. Thus, $b$ represents the coefficients for variable $\mathrm{i}, \mathrm{b}_{\mathrm{ij}}$ the coefficients for variable interactions $\mathrm{i}$ and $\mathrm{j}$, and $\mathrm{b}_{\mathrm{ijk}}$ the coefficient for variable interactions $\mathrm{i}, \mathrm{j}$, and $\mathrm{k}$.

A linear regression was performed to determine the model coefficients and, due to the orthogonality property for the design, those coefficients are independent of each other and can be interpreted separately. Thus, the larger the coefficient the greater the variable importance. This model may be used to predict responses using processing parameters for which experiment has not been performed.

In order to validate the model, samples were produced using intermediate processing parameters values in the range studied, namely a calciumdeficient hydroxyapatite powder with $\mathrm{Ca} / \mathrm{P}$ ratio of $1.62,30 \mathrm{wt}$. (\%) of naphthalene and calcination temperature of $1075^{\circ} \mathrm{C}$. Phase composition and total porosity were then determined following the same procedures previously described. Those samples were also submitted to a compression test by using a universal electromechanical testing machine (Instron, model 1125 , USA) with a cross-head speed of $0.5 \mathrm{~mm} / \mathrm{min}$.

\section{Results}

Figure 1 shows the macrography of porous calcium phosphate

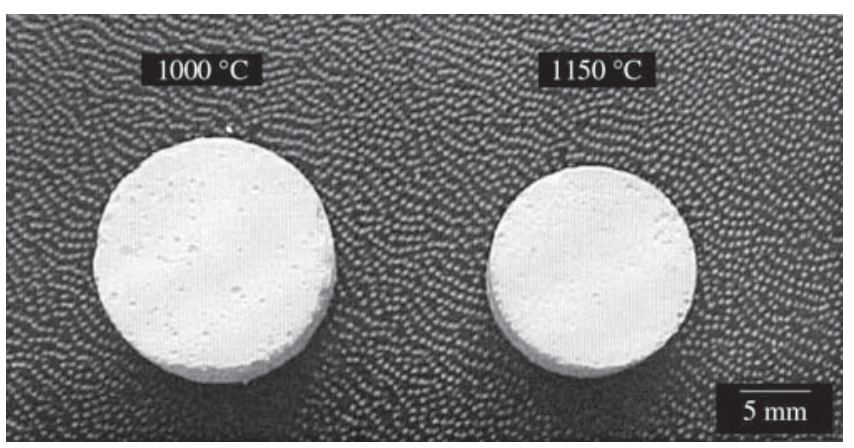

Figure 1. Macrography of samples calcined at 1000 (left) and $1150{ }^{\circ} \mathrm{C}$ (right). 
(CP) samples after calcination at temperatures of $1000{ }^{\circ} \mathrm{C}$ and $1150{ }^{\circ} \mathrm{C}$. Volumetric shrinkage at $1150{ }^{\circ} \mathrm{C}$ was about $26 \%$, indicating that the densification process was very efficient at that temperature. Figure 2 shows the SEM image of the large pores $(>200 \mu \mathrm{m})$ of the sample calcined at $1075^{\circ} \mathrm{C}$. The measured compressive strength for this sample was $4.0 \pm 0.9 \mathrm{MPa}$. This result is in accordance with data reported by Suchanek and Yoshimura ${ }^{3}$, which indicated a dramatically decrease in compressive strength with the increase in sample porosity. The macropores distribution for S-HA and CD-HA samples calcined at $1000{ }^{\circ} \mathrm{C}$ have a similar pattern and are mainly concentrated in the range of 300-400 $\mu \mathrm{m}$ (Figure 3a-b). The surface micropores in S-HA samples after calcination at $1000{ }^{\circ} \mathrm{C}$ can be visualized in Figure 4. Micropore size was $2 \mu \mathrm{m}$ or less.

The data concerning the porosity resulted from the use of the eight conditions selected are shown in Table 2 . The values of porosity

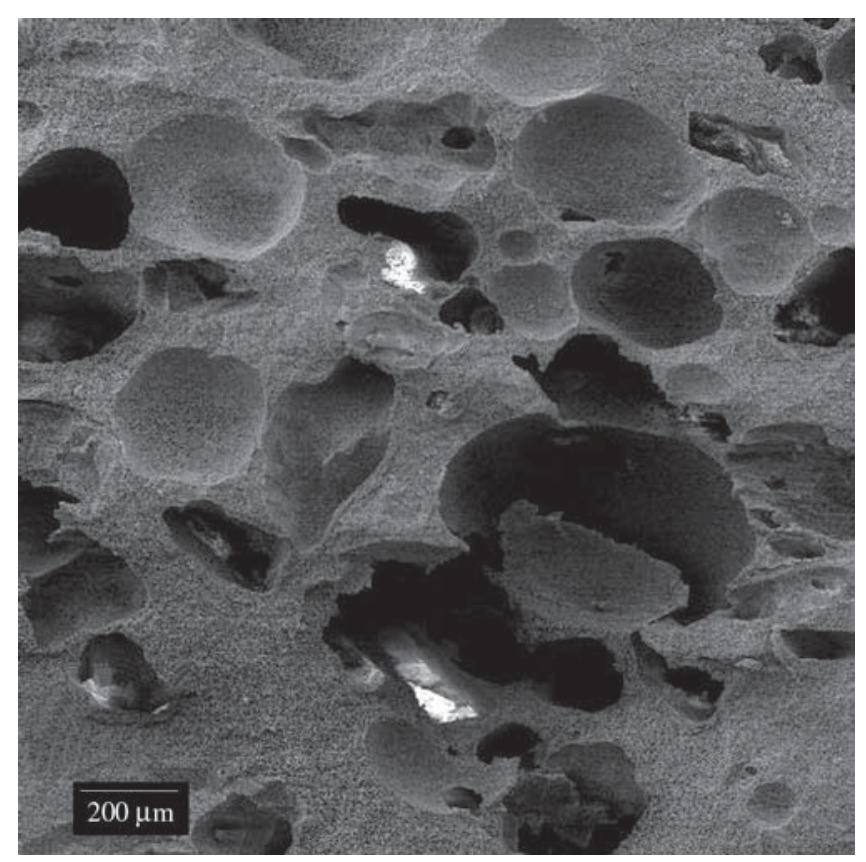

Figure 2. SEM image of the cross section of the samples produced with $\mathrm{Ca}$ / $\mathrm{P}=1.62 ; 30 \mathrm{wt}$. (\%) of naphthalene and calcination temperature of $1075^{\circ} \mathrm{C}$.
Table 2. Porosity (\%) determined by density calculation and macroporosity measured by processing SEM digital images.

\begin{tabular}{lcc}
\hline \multicolumn{1}{c}{ Sample } & \multicolumn{2}{c}{ Porosity (\%) Measured by } \\
& Density & Image Analysis \\
\hline S-20-1000 & $71.4 \pm 0.6$ & 24.3 \\
S-20-1150 & $51.7 \pm 0.6$ & n.d. \\
S-40-1000 & $77.6 \pm 0.4$ & 38.4 \\
S-40-1150 & $65.4 \pm 0.9$ & n.d. \\
CD-20-1000 & $72.1 \pm 0.7$ & 20.9 \\
CD-20-1150 & $53.5 \pm 0.3$ & n.d. \\
CD-40-1000 & $78.1 \pm 0.3$ & 32.7 \\
CD-40-1150 & $66.0 \pm 0.9$ & n.d. \\
\hline
\end{tabular}

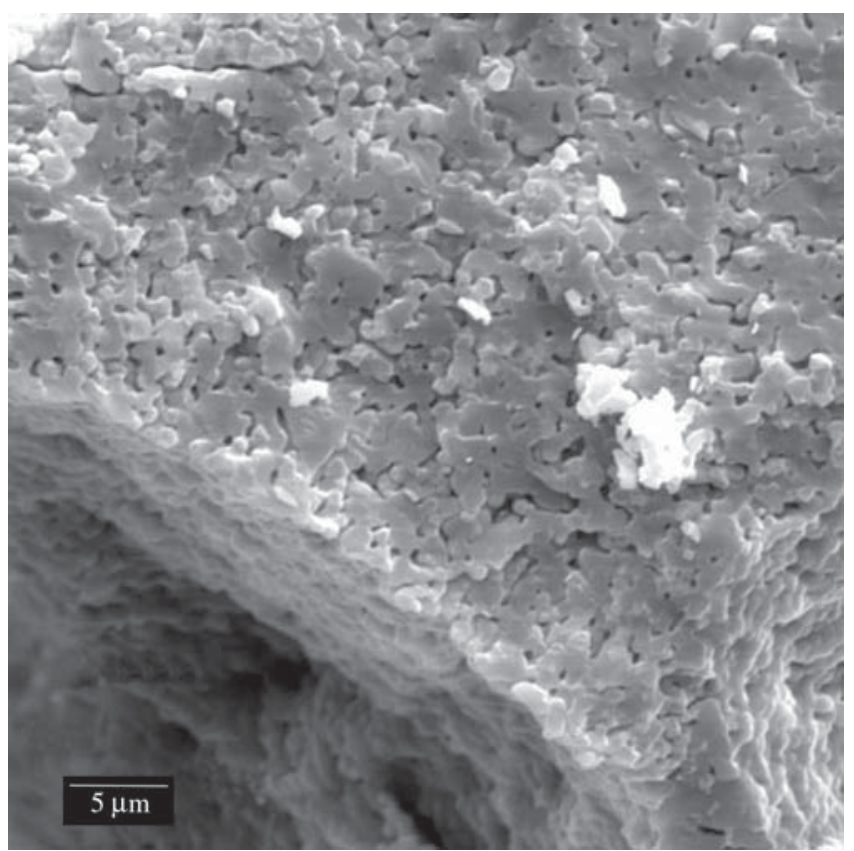

Figure 4. SEM image showing microporosity produced with stoichiometric HA (S-HA) calcined at $1000^{\circ} \mathrm{C}$.

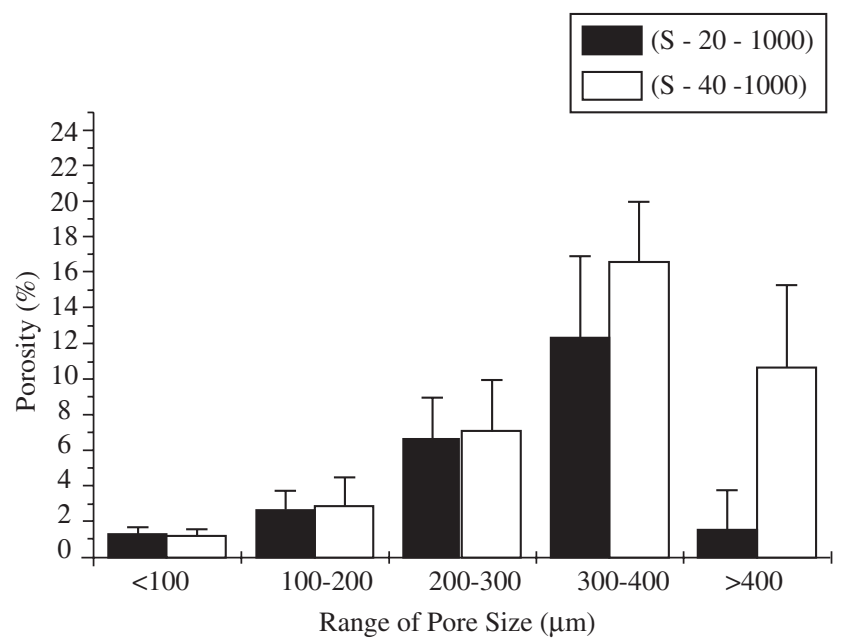

(a)

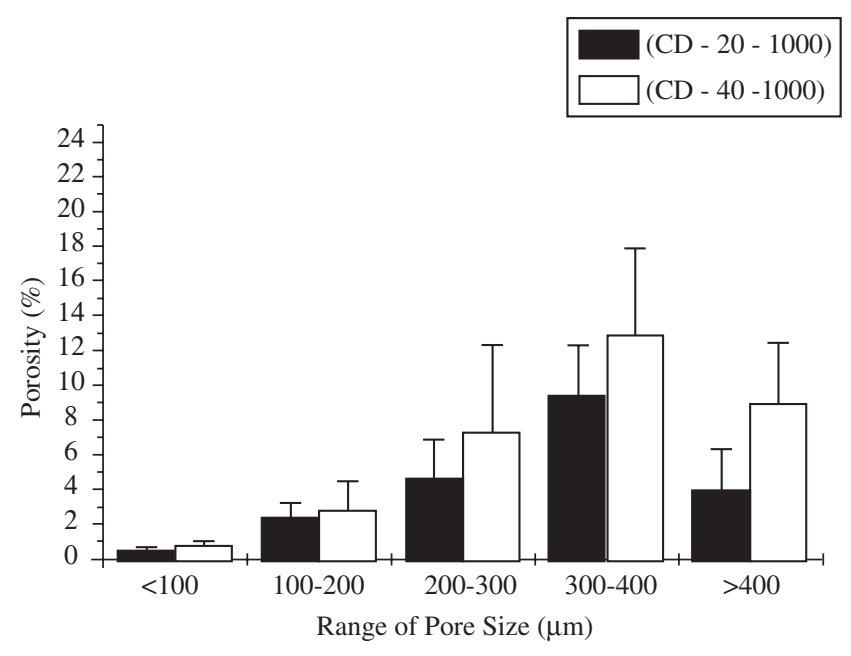

(b)

Figure 3. Pore size distribution for: a) S-HA; b) CD-HA samples calcined at $1000^{\circ} \mathrm{C}$. 
were determined by density measurements (all samples) and digital SEM images (for samples calcined at $1000{ }^{\circ} \mathrm{C}$ ). Table 2 shows that total sample porosity was affected by porogen content and calcination temperature. The total porosity for S-HA and CD-HA samples calcined at $1000{ }^{\circ} \mathrm{C}$ increased by nearly $8 \%$ when the naphthalene content changed from $20 \%$ to $40 \%$. On the other hand, the porosity measured by image analysis considered basically macroporosity and showed variation of nearly $60 \%$ for the same conditions.

The FTIR spectra of porous S-HA samples with 20 and $40 \mathrm{wt}$. (\%) of naphthalene calcined at 1000 (a) and $1150{ }^{\circ} \mathrm{C}$ (b) are shown in Figure 5a-b. Both spectra have similar FTIR bands but with different relative intensities, which can be due to variations in the samples surface composition. Vibration mode in HA, $\alpha$-TCP and surface phosphates phases, such as $\beta-\mathrm{Ca}_{2} \mathrm{P}_{2} \mathrm{O}_{7}$, contribute to FTIR spectra. The characteristic $\mathrm{OH}^{-}$absorption bands of HA were observed at
$3575 \mathrm{~cm}^{-1}$ and $640 \mathrm{~cm}^{-1}$, while the bands at $1650 \mathrm{~cm}^{-1}$ were assigned to physically adsorbed water molecules. The band around 1392 can be attributed to residual nitrate groups resultant from synthesis precursors. The presence of $\mathrm{C}-\mathrm{O}$ vibrations bands of $\mathrm{CO}_{3}{ }^{2-}$ groups at $875 \mathrm{~cm}^{-1}$ and $1414-1545 \mathrm{~cm}^{-1}$ regions suggests that there is some carbonate present, which is commonly found in both synthetic HA and natural bones. The bands at $1208,1162,1104$ and $1060 \mathrm{~cm}^{-1}$ may be associated to $\beta$-calcium pyrophosphate $\left(\beta-\mathrm{Ca}_{2} \mathrm{P}_{2} \mathrm{O}_{7}\right)$ and $\alpha$-tricalcium phosphate $(\alpha-$-TCP). The other bands at 1092, 1044, 1036, 960, 573, and $475 \mathrm{~cm}^{-1}$ were assigned to the vibration in the $\mathrm{PO}_{4}{ }^{3-}$ group of the hydroxyapatite (HA).

The FTIR spectra of porous samples produced with CD-HA show strong $\beta$-tricalcium phosphate ( $\beta$-TCP) bands at $1120,1042,971,948$, 604 and $433 \mathrm{~cm}^{-1}$ for samples calcined at $1000{ }^{\circ} \mathrm{C}$ (Figure 6a-b). The carbonate bands are more intense than those in S-HA spectra.

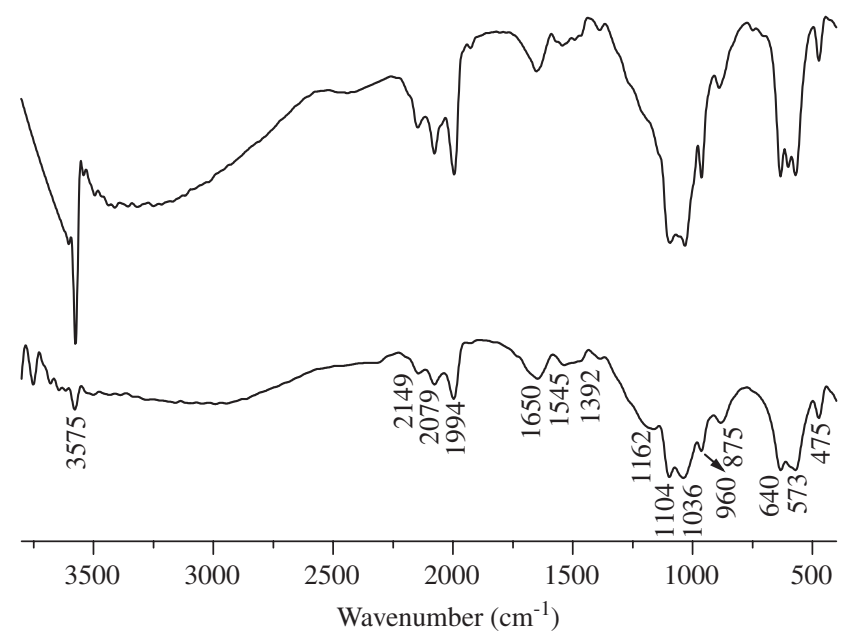

(a)

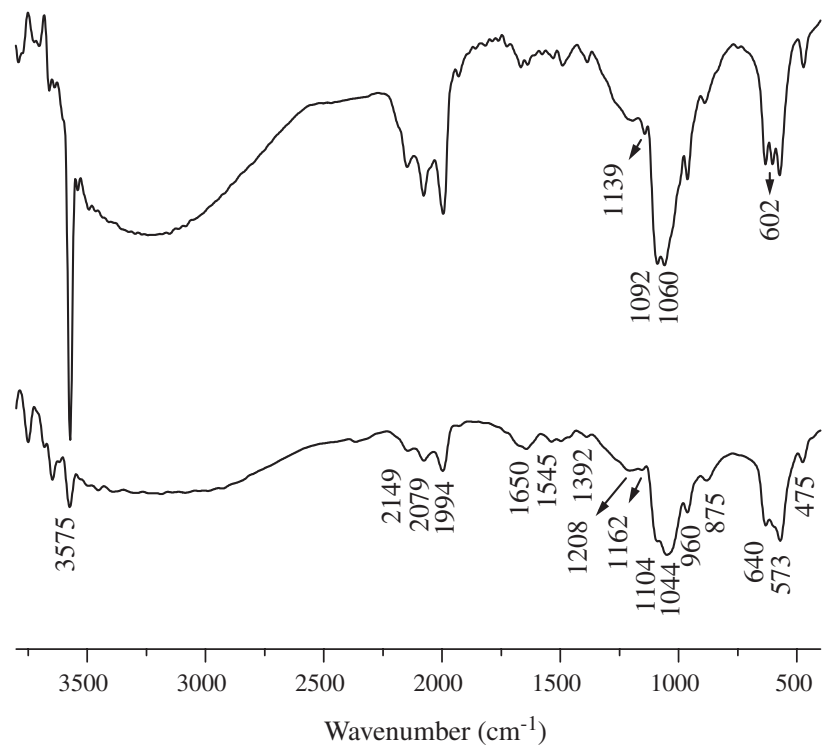

(b)

Figure 5. FTIR spectra of the samples produced with stoichiometric hydroxyapatite (S-HA) and naphthalene $(20$ or 40 wt. $(\%))$ calcined at: a) $1000{ }^{\circ} \mathrm{C}$; b) $1150{ }^{\circ} \mathrm{C}$.

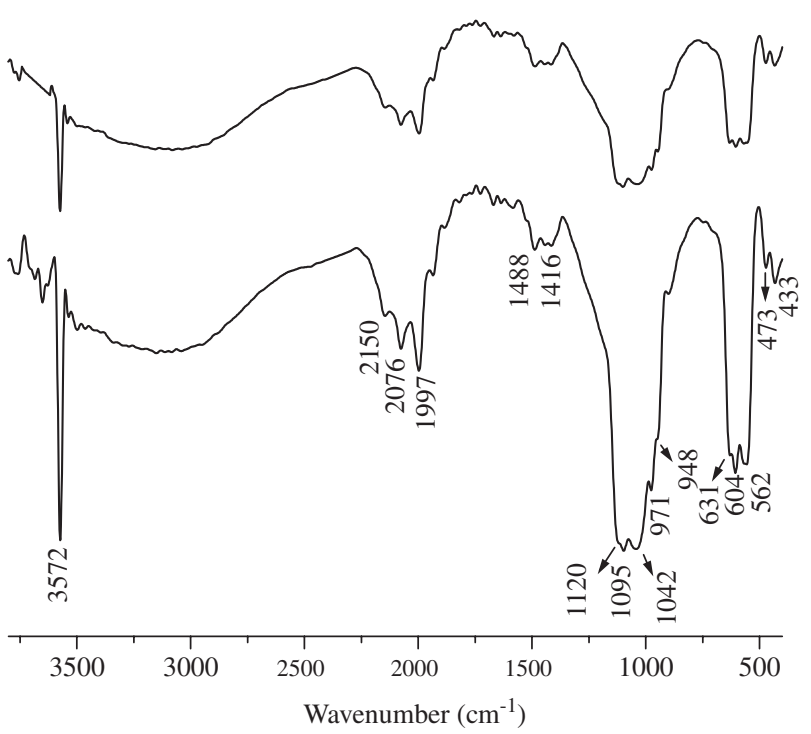

(a)

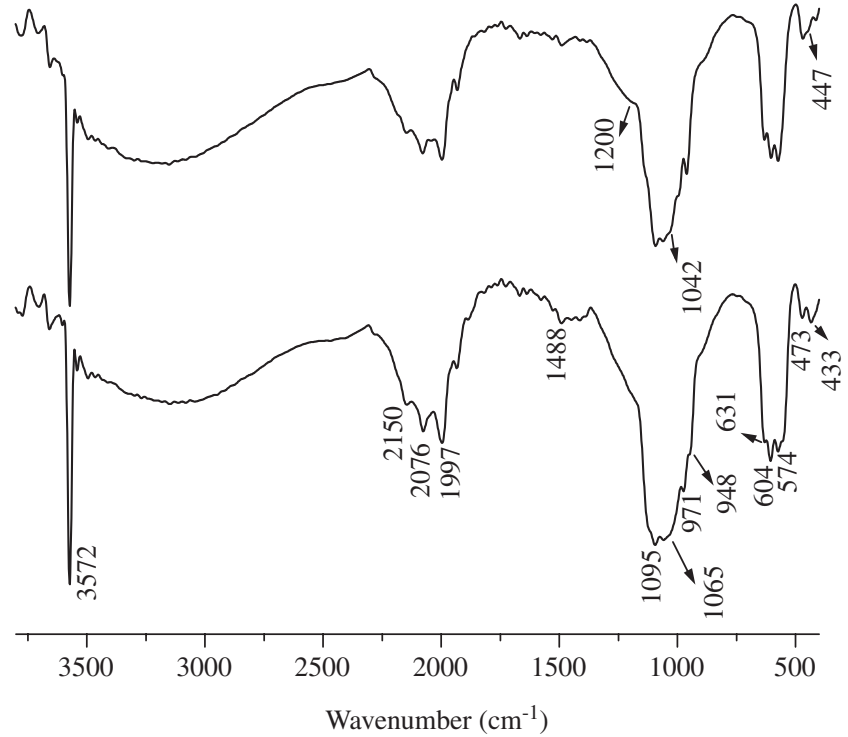

(b)

Figure 6. FTIR spectra of the samples produced with calcium-deficient hydroxyapatite (CD-HA) and naphthalene $(20$ or 40 wt. $(\%))$ calcined at: a) $1000{ }^{\circ} \mathrm{C}$; b) $1150{ }^{\circ} \mathrm{C}$. 
The phase content for calcined samples produced from the S-HA and the CD-HA at different calcination temperatures and naphthalene contents were determined by XRD analysis. The results are shown in Table 3. For $\mathrm{S}-\mathrm{HA}$ samples $(\mathrm{Ca} / \mathrm{P}=1.67)$, calcination promotes the HA decomposition, and $\alpha-\mathrm{TCP}$ is produced in a fraction varying from 10.5 to $19.3 \%$. For CD-HA samples, the HA decomposition is more intense, but either $\beta$-TCP or $\alpha$-TCP can be formed, depending on the sample calcination temperature and naphthalene content before calcination. For samples calcined at $1000^{\circ} \mathrm{C}, \beta$-TCP is the only phase present besides HA, irrespective of the naphthalene content. When samples are calcined at $1150{ }^{\circ} \mathrm{C}, \alpha$-TCP changes from 6.5 to $55.5 \%$ for samples with $20 \%$ and $40 \%$ of naphthalene, respectively.

The analytical expressions that quantitatively correlate the $x_{i=1-3}$ variables (HA stoichiometry, calcination temperature and naphthalene content) with $Y_{j}$ responses (phase content and total porosity) through the variable $b_{i}$ coefficients were thus determined by using the results shown in Tables 2 and 3, as follows:

$$
\begin{aligned}
& \mathrm{Y}_{\text {HA phase }}=65+39 \mathrm{x}_{1}+4 \mathrm{x}_{2}+1 \mathrm{x}_{3}-3 \mathrm{x}_{1} \mathrm{x}_{2}+0.1 \mathrm{x}_{1} \mathrm{x}_{3}+ \\
& 0.6 \mathrm{x}_{2} \mathrm{x}_{3}+0.9 \mathrm{x}_{1} \mathrm{x}_{2} \mathrm{x}_{3} \\
& \mathrm{Y}_{\text {HA porosity }}=67-1 \mathrm{x}_{1}-16 \mathrm{x}_{2}+10 \mathrm{x}_{3}-0.3 \mathrm{x}_{1} \mathrm{x}_{2}+0.4 \mathrm{x}_{1} \mathrm{x}_{3}+ \\
& 4 \mathrm{x}_{2} \mathrm{x}_{3}+0.2 \mathrm{x}_{1} \mathrm{x}_{2} \mathrm{x}_{3}
\end{aligned}
$$

The variables $\mathrm{x}_{1} \mathrm{x}_{2}$ and $\mathrm{x}_{3}$ represent, respectively, calcium phosphate $\mathrm{Ca} / \mathrm{P}$ ratio, calcination temperature and naphthalene percentage. Due to the fact that the variable levels were coded as $(-1)$ and $(+1)$, the larger the coefficient absolute value, the higher its influence on the response. Therefore, the results show that phase transformation is basically influenced by the $\mathrm{Ca} / \mathrm{P}$ ratio (coefficient $=39$ ), while the percentage of naphthalene and calcination temperature affect the total porosity.

\section{Discussion}

Using a $2^{3}$ factorial design eight different porous $\mathrm{CP}$ samples were produced. The analysis of Table 3 and Equations 2 and 3 shows that the major variable affecting samples composition is the $\mathrm{Ca} / \mathrm{P}$ ratio of the powder employed, as the calcium-deficient hydroxyapatite is less stable than the stoichiometric one. The calcination temperature is the second parameter that affects calcium phosphate decomposition. S-HA was partially decomposed into an $\alpha$-TCP that is thermodynamically stable in the range $1120-1470{ }^{\circ} \mathrm{C}^{4}$. The decomposition observed for the samples produced with stoichiometric hydroxyapatite (S-HA) could be induced by small quantities of amorphous HA, carbonate ions or variations in calcium phosphate stoichiometry, ${ }^{5,24}$. Similar decomposition reaction occurs for S-HA samples calcined without naphthalene and for calcined powdered S-HA samples ${ }^{25}$. Calcium deficient HA (CD-HA) decomposed in either $\beta$-TCP or $\alpha$-TCP phase depending on the calcination temperature and naphthalene content, as expected for a hydroxyapatite with $\mathrm{Ca} / \mathrm{P}$ ratio between 1.50 and $1.67^{26}$.

Due to the high instability of CD-HA, the change in the calcination temperature from 1000 to $1150{ }^{\circ} \mathrm{C}$ did not significantly increase the quantity of HA transformed. According to Table 3, naphthalene content has a minor effect on phase transformation, but it seems to affect the $\beta$-TCP $\rightarrow \alpha$-TCP transformation, at least for CD-HA samples. This conclusion is supported by the comparison of phase content of CD-20-1150 (45.2\% of HA, $6.5 \%$ of $\alpha$-TCP and $48.3 \%$ of $\beta$-TCP) with CD-40-1150 (45.5\% of HA and $55.5 \%$ of $\alpha$-TCP), but the reasons underlying these findings are not clearly understood. Besides, additional factors such as naphthalene residues due to thermal treatment may also influence the interfacial reactions responsible for this type of crystalline phase transition. The use of biphasic systems is widely spread as TCP phase is more soluble than HA and its presence increases slow crack growth susceptibility and biodegradability of the HA ceramics ${ }^{18,27}$. This material is generally obtained through the physical mixture of $\mathrm{HA}$ with $\beta-\mathrm{TCP}^{28}$, but it can also be obtained through the controlled decomposition of CD-HA.

The porogen was used to create macroporosity but it also produced, a slight increase $(\sim 10 \%)$ in sample microporosity. The range of porosity varied from $\sim 52 \%$ (sample S-20-1150) to $~ 78 \%$ (sample CD-40-1000). According to Figure 3, for samples calcined at $1000{ }^{\circ} \mathrm{C}$, the distribution of pores shows that the maximum frequency of pore diameter is around $300-400 \mu \mathrm{m}$, with pores even greater than $400 \mu \mathrm{m}$. Those pore sizes may allow normal bone remodeling processes ${ }^{1,29}$, although other features such as in vivo resorbability were not evaluated. Unfortunately, the methodology used in this study produced low level of interconnected pores. One way to obtain highly porous 3 -dimensional scaffolds is by using polymeric foams ${ }^{17}$.

Equation 2 shows that sample phase content is predominantly influenced by $\mathrm{Ca} / \mathrm{P}$ molar ratio. Porosity is sensitive to both calcination temperature and porogen content, but the effect of calcination temperature is stronger because in Equation 3, $\left|b_{2}\right|>\left|b_{3}\right|$. These results suggest that coupling low calcination temperatures with high porogen content may optimize sample porosity. However, this is limited by the effect of porosity on sample mechanical strength. The results measured for the sample produced with the intermediate conditions and the values calculated using the model proposed are presented in Table 4 . A total porosity of $73 \%$ and a composition consisting of $63 \% \mathrm{HA}$ and $37 \% \beta$-TCP was obtained. It is seen that the uncertainty associated with the experimental values is small, suggesting a good process reproducibility for the attainment of the porous samples.

\section{Conclusions}

The results indicate that the $2^{3}$ factorial design method may provide useful information on the production of porous calcium phosphate with controlled texture and phase composition. In this

Table 3. Phases identified by XRD analysis and quantified using the Rietveld method

\begin{tabular}{cccc}
\hline \multicolumn{1}{c}{ Sample } & \multicolumn{3}{c}{ Phase Content (wt. (\%)) } \\
& HA & $\alpha$-TCP & $\beta$-TCP \\
\hline S-20 - 1000 & 89.5 & 10.5 & -- \\
S-20 - 1150 & 81.3 & 18.7 & -- \\
S-40 - 1000 & 85.9 & 14.1 & -- \\
S-40 - 1150 & 80.7 & 19.3 & -- \\
CD-20 - 1000 & 45.3 & -- & 54.7 \\
CD - 20 - 1150 & 45.2 & 6.5 & 48.3 \\
CD - 40 - 1000 & 45.2 & -- & 54.8 \\
CD - 40 - 1150 & 44.5 & 55.5 & -- \\
\hline
\end{tabular}

Table 4. Differences between predicted and experimental values of sample produced with $\mathrm{Ca} / \mathrm{P}$ ratio of $1.62,30 \mathrm{wt}$. (\%) of naphthalene and calcination temperature of $1075^{\circ} \mathrm{C}$.

\begin{tabular}{ccc}
\hline $\begin{array}{c}\text { Results } \\
(\text { wt. }(\%))\end{array}$ & Predicted & Experimental \\
\hline HA phase & 64.7 & $63.4 \pm 0.4$ \\
total porosity & 66.9 & $72.8 \pm 0.4$ \\
macroporosity & 30.0 & $36.4 \pm 0.4$ \\
microporosity & 37.2 & $36.4 \pm 0.8$ \\
\hline
\end{tabular}


work, the phase composition of calcined samples was basically a function of $\mathrm{Ca} / \mathrm{P}$ ratio of the raw material. As expected, porosity was sensitive to both calcination temperature and porogen content, but the effect of calcination temperature was stronger.

\section{Acknowledgements}

Financial support was received from several Brazilian agencies like CAPES, FAPERJ and FUJB. This research is part of the RENAMI and IMBT projects, supported by CNPq. The authors would also like to acknowledge Catalysis Group of COPPE/UFRJ for X-ray diffraction and the CETEM Institute for infrared spectroscopy.

\section{References}

1. Burg KJL, Porter S, Kellam JF. Biomaterial developments for bone tissue engineering. Biomaterials. 2000;21(23):2347-2359.

2. Aoki H. Medical applications of hydroxyapatite. St. Louis: Ishyaku EuroAmerica Inc.;1994.

3. Suchanek WL, Yoshimura M. Processing and Properties of Hydroxyapatite-Based Biomaterials for use as Hard Tissue Replacement Implants. Journal of the American Ceramic Society. 1998;13(1):94-117.

4. Ducheyne P, Qiu Q. Bioactive ceramics: the effect of surface reactivity on bone formation and bone cell function. Biomaterials. 1999;20(2324):2287-2303.

5. LeGeros RZ. Properties of osteoconductive biomaterials: calcium phosphates. Clinical Orthopaedics and Related Research. 2002;395:81-98.

6. Hench LL. Bioactive ceramics. Annals of The New York Academy of Sciences. 1988;523:54-71.

7. Chang B-S, Lee C-K, Hong K-S, Youn H-J, Ryu H-S, Chung S-S, et al. Osteoconduction at porous hydroxyapatite with various pore configurations. Biomaterials. 2000;21(12):1291-1298

8. Rhee S-H, Tanaka J. Hydroxyapatite coating on a collagen membrane by a biomimetic method. Journal of the American Ceramic Society. 1998;81(11): 3029-3031.

9. Sena LA, Serricella P, Borojevic R, Rossi AM, Soares GA. Synthesis and characterization of hydroxyapatite on collagen gel. Key Engineering Materials. 2004; 254-256:493-496.

10. Boyde A, Corsi A, Quarto R, Cancedda R, Bianco P. Osteoconduction in large macroporous hydroxyapatite ceramic implants: evidence for a complementary integration and disintegration mechanism. Bone. 1999; 6:579-589.

11. Hing KA, Best SM, Tanner KE, Bonfield W, Revell PA. Quantification of bone ingrowth within bone-derived porous hydroxyapatite implant of varying density. Journal of Materials Science. Materials In Medicine. 1999; 10(10-11):663-670.

12. Ducheyne P, Radin S, King L. The effect of calcium phosphate ceramic composition and structure on in vitro behavior. I. Dissolution. Journal of Biomedical Materials Research. 1993; 27(1):25-34.

13. Geesink RG, De Groot K, Klein CP. Bonding of bone to apatite-coated implants. The Journal of Bone and Joint Surgery. 1988;70(1):17-22.

14. Frayssinet P, Trouillet JL, Rouquet N, Azimus E, Autefage A. Osseointegration of macroporous calcium phosphate ceramics having a different chemical composition. Biomaterials. 1993; 14(6):423-429.
15. Lu JX, Flautre B, Anselme K, Hardouin P, Gallur A, Descamps M et al. Role of interconnections in porous bioceramics on bone recolonization in vitro and in vivo. Journal of Material Science. Materials in Medicine. 1999;10(2):111-120.

16. Dorozhkin SV, Dorozhkina EI. Mechanism of the solid state transformation of a calcium-deficient hydroxyapatite (CDHA) into biphasic calcium phosphate (BCP) at elevated temperatures. Chemical Materials. 2002; $14: 4267-4272$.

17. Baksh D, Davies JE. Design Strategies for 3-Dimensional Bone Tissue In Vitro. In Davies JE, editor. Bone Engineering. Toronto: Interrobang Cgraphic Design Inc.; 2000. p. 488-495.

18. Dorozhkin SV. A review on the dissolution models of calcium apatites. Progress in Crystal Growth and Characterization of Materials. 2002; 44(1):45-61.

19. Gauthier O, Bouler J-M, Aguado E, Pilet P, Daculsi G. Macroporous biphasic calcium phosphate ceramics: influence of macropore diameter and macroporosity percentage on bone ingrowth. Biomaterials. 1998;19(1-3):133-139.

20. Sous M, Bareille R, Rouais F, Clément D, Amédée J, Dupuy B et al. Cellular biocompatibility and resistance to compression of macroporous $\beta$ tricalcium phosphate ceramics. Biomaterials. 1998;19(23):2147-2153.

21. Bouler JM, Trécant M, Delécrin J, Royer J, Passuti N, Daculsi G. Macroporous biphasic calcium phosphate ceramics: influence of five synthesis parameters on compressive strength. Journal of Biomedical Materials Research. 1996;32(4):603-609.

22. Massart DL, Aguiar PF. Experimental Design. In Schleyer, editor. The Encyclopedia of Computational Chemistry. Sussex: John Wiley and Sons; 1998. cap. III.

23. Rodriguez-Carvajal J. FULLPROF: A Program for Rietveld Refinement and Pattern Matching Analysis. In: Proceedings of the Satellite Meeting on Powder Diffraction of the XV Congress of the International Union of Crystallography; 1990; Bordeaux, France. Bordeaux: IUCr; 1990. p. 127.

24. Petrov OE, Dyulgerova E, Petrov L, Popova R. Characterization of calcium phosphate phases obtained during the preparation of sintered biphase Ca-P ceramics. Materials Letters. 2001;48(3-4):162-167.

25. Oliveira JF. Efeito dos parâmetros de processamento nas características de cerâmicas porosas à base de fosfato de cálcio para aplicação em engenharia óssea. [Unpublished D. Phil thesis]. Rio de Janeiro: Universidade Federal do Rio de Janeiro; 2003.

26. Raynaud S, Champion E, Bernache-Assollant D, Thomas P. Calcium phosphate apatites with variable $\mathrm{Ca} / \mathrm{P}$ atomic ratio I. Synthesis, characterization and thermal stability of powders. Biomaterials. 2002;23(4):10651072.

27. Landi E, Tampieri A, Celotti G, Sprio S. Densification behaviour and mechanisms of synthetic hydroxyapatites. Journal of the European Ceramic Society. 2000;20(14-15):2377-2387.

28. Krajewski A, Ravaglioli A, Mongiorgi R, Moroni A. Mineralization and calcium fixation within a porous apatitic ceramic material after implantation in the femur of rabbits. Journal of Biomedical Materials Research. 1988;22(6):445-457.

29. Pilliar RM, Filiaggi MJ, Wells JD, Grynpas MD, Kandel RA. Porous calcium polyphosphate scaffolds for bone substitute applications - In vitro characterization. Biomaterials. 2001; 22(9):963-972. 